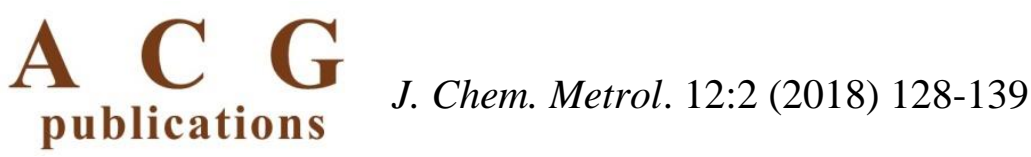

journal of chemical metrology

\title{
Determination of some major and trace elements in the lower Sakarya River water by ICP-MS
}

\author{
Mustafa S. Dündar and $^{*}$ Huseyin Altundăg \\ Sakarya University, Faculty of Arts and Sciences, Department of Chemistry, 54187, \\ Sakarya, Turkiye
}

(Received December 01, 2018; Revised December 17, 2018; Accepted December 18, 2018)

\begin{abstract}
In this paper, water and sediment samples were collected along the Lower Sakarya River basin for a twelve month period between February 2007 and January 2008. The samples were analysed for trace elements (31 elements in sediment and 33 elements in water) using the ICP-MS technique as pollution indicators. The results indicated that the Sakarya River water was polluted by sources of beryllium and thallium which exceeded the limits set by US Environmental Protection Agency (USEPA 2003). Sediments were polluted by Antimony, Tin, Rhodium and Selenium. The results also provide useful data for the conservation of the Black Sea where it is joined by the Sakarya River.
\end{abstract}

Keywords: Sakarya river; river water; sediment; heavy metal; ICP-MS; environmental. (C) 2018 ACG Publications. All rights reserved.

\section{Introduction}

The Sakarya River is one of the most important watersheds in the northwest part of Turkey and is a water source for irrigation, wastewater dilution, and industries. The watershed consists of three parts: the Upper, Middle, and Lower Sakarya River Basins. In this paper the lower part of the river basin was studied. There are five provinces within the Sakarya River Basin namely, Ankara, Kutahya, Eskisehir, Bilecik, and Sakarya, where the river drains into the Black Sea.

Various studies have been carried out in the major rivers of Turkey, such as the Buyuk Menderes and Gediz [1], Kizilirmak [2], Yeşilirmak [3], Firat [4], Tigris (Dicle) [5], and Mert Irmağ1 [6]. Water, the most important natural resource in the world, has the unique property of dissolving and carrying in suspension a huge variety of chemicals; hence, water can easily become contaminated [7]. Among the inorganic contaminants of river water, heavy metals [8,9] are important because of their non-degradable nature. Although some papers on the assessment of water quality based on physico-chemical and biological parameters have been published $[10,11]$ very little information is available about the status of heavy metal contamination of the river Sakarya. With this background an investigation was initiated.

In an aquatic environment many anthropogenic pollutants are bound or absorbed by particulate matters. Depending on river conditions, suspended particles can settle and become part of the bottom sediments. Many studies reported the release of contaminants from surface sediments $[12,13]$ depending on the aquatic conditions. A source of contaminants can make sediment chemistry and toxicity key

* Corresponding author; E-mail: dundar@ sakarya.edu.tr ; Phone:+90 26429460 44; Fax:+90 2642955950 
components of aquatic system quality. Moreover, such concentrations are often highly variable because of several interacting factors, such as source characteristics, the flow regimes of the river and receiving waters, as well as their mixing dynamics [13].

The three main objectives of this paper are as follows: (a) The first goal was to obtain a comprehensive description of the physical, chemical properties and trace metal contents of the Lower Sakarya River water and trace metal contents of sediments. Only a few previous studies examined this river, always from a few sites of interest or single "hot spots". (b) The second aim was to assess whether hazardous conditions may derive from the sediments and threaten the aquatic community. Only limited, scattered information is available on the risk posed by sediments. (c) The third main objective was to evaluate the usefulness of the different indicators (and approaches) to discriminate the quality changes along the Lower Sakarya River. To accomplish these three major objectives, water and sediment samples were collected from various locations of the river [14,15], and according to a defined procedure, they were concurrently examined for a range of physical, chemical and trace metal contents. The present study describes and discusses the principal results of the Lower Sakarya River water and sediment analysis.

\section{Experimental}

\subsection{Sampling and analysis}

In total, 240 river water samples were collected throughout the Lower Sakarya River during a twelve month period. Water samples were collected at selected sites (Çardak (1), Alifuatpaşa (2), Doğançay (3), Adliye (4), E-5 Sakarya Köprüsü, Rüstemler (5), Sinanoğlu (6), Adatepe (7), Tuzla (8), Karasu (9)) all located along the Lower Sakarya River (Figure 1 and Table 1).

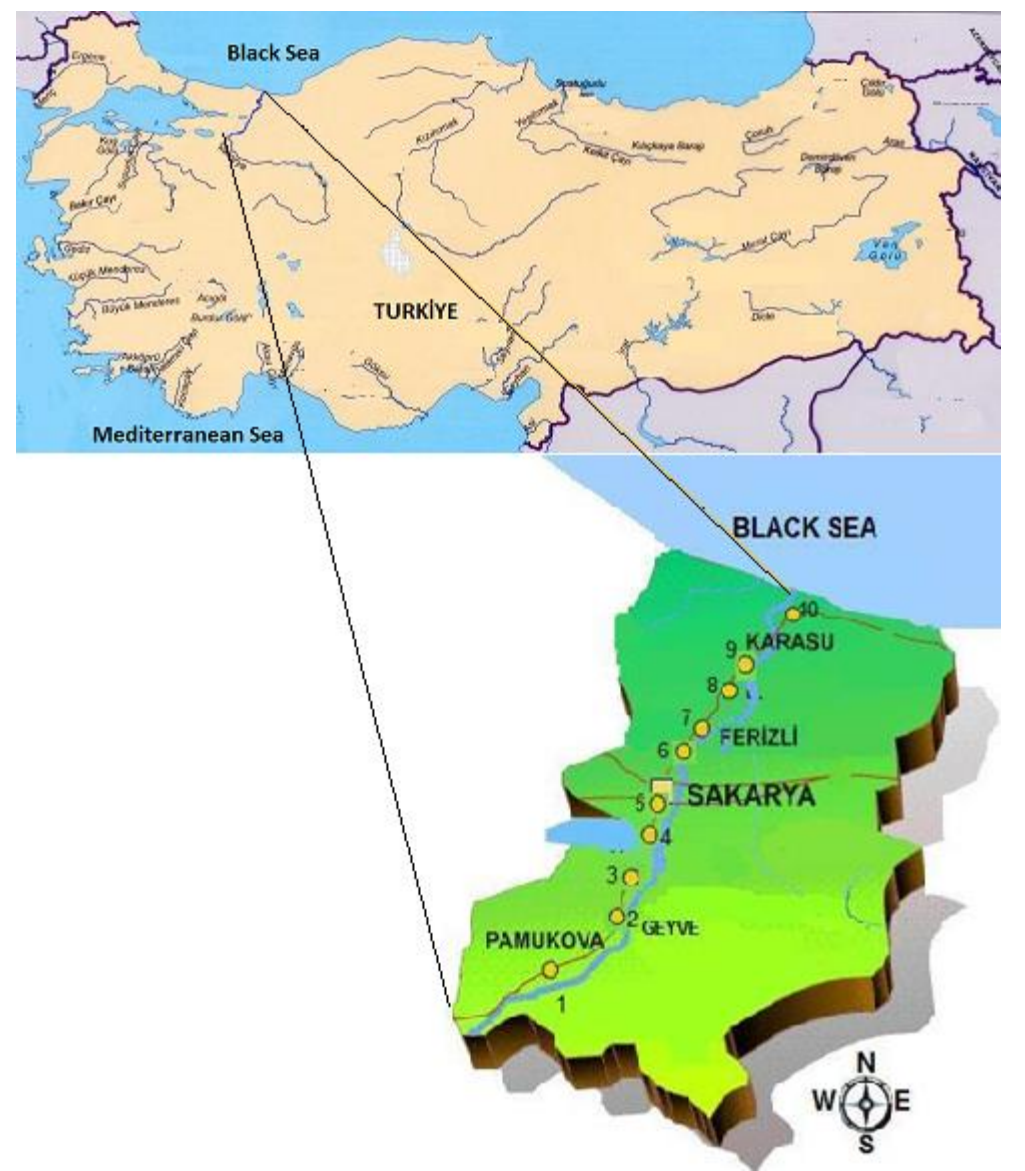

Figure 1. Shematic representation of Lower Sakarya River Water [14] 
The samples were taken in duplicate, in 0.5 L polyethylene plastic bottles, using a Nansen type water sampler, between February 2007 and January 2008. After collection, the water samples destined to metal analysis were acidified with $\mathrm{HNO}_{3}$. Sample properties $(\mathrm{pH}$, temperature, dissolved oxygen, biological oxygen demand, salinity, alkalinity, etc.) were recorded according to Turkish standards (TS 5089, TS 5090, and TS 5106). Sulfate (TS 5095), Phosphate (TS 4082), Nitrate (TS 7890), and Chloride (TS 4164) in water samples were analysed in the laboratory. A coloured soft water from Quebec (Trois94) was used for validation of the water analysis. River water reference material for trace metals, SLRS4 were used for validation of the water analysis.

In total, 200 sediment samples were collected during a 10-month period between February 2007 and January 2008. Surface sediment samples were collected at selected sites (Table 1) on the Lower Sakarya River $[14,15]$.

Table 1. Coordinates of the sampling sites in the Lower Sakarya River [15]

\begin{tabular}{|c|c|c|c|c|c|c|c|c|c|c|c|}
\hline Sampling Station & & 1 & 2 & 3 & 4 & 5 & 6 & 7 & 8 & 9 & 10 \\
\hline \multirow{2}{*}{ Coordinates $\left({ }^{\circ}{ }^{\prime} "\right)$} & East & 300934 & 301749 & 301952 & 302244 & 302520 & 302612 & 303032 & 303608 & 303838 & 303847 \\
\hline & North & 402809 & 403206 & 403729 & 404016 & 404422 & 404776 & 405752 & 410130 & 410451 & 410708 \\
\hline
\end{tabular}

The samples were collected in duplicate, in $250 \mathrm{~mL}$ polyethylene bottles using an Ekman-Birge type grab sampler, [TS 9547 ISO 5667-12 method (Water quality-sampling section 12: Guide to bottom sediment sampling)]. After collection, sediment samples were digested in graphite crucible (ASTM D 4698). Samples were not collected in July and August due to the loss of an Ekman-Grab bottom sampler. Sediment samples were sieved using sieves with pore sizes below $0.074 \mathrm{~mm}$. Sediments were used in elemental analysis within one week of collection.

Sediment samples were digested using TS 9265 [Water quality-Total digestion of sediment samples before chemical analysis of various metals (ASTM D 4698)] standart before elemental analysis. Trace metals in sediment samples were analysed by using ICP-MS technique.

River sediment reference material for trace metals are; STSD-1, chinese stream sediment, and NCS DC73312, were used for validation of the sediment analysis. Samples were digested using TS 9265 [Water quality-Total digestion of sediment samples before chemical analysis of various metals (ASTM D 4698)] standard before elemental analysis.

A total of 33 elements in water (vanadium, chromium, manganese, iron, cobalt, nickel, copper, zinc, aluminium, boron, cadmium, arsenic, selenium, antimony, lead, calcium, magnesium, thorium, molybdenum, barium, strontium, beryllium, lithium, sodium, potassium, gallium, wolfram, tantalum, bismuth, titanium, rhodium, thallium, silicon) and sediment samples (vanadium, chromium, manganese, iron, cobalt, nickel, copper, zinc, aluminium, arsenic, selenium, antimony, lead, calcium, magnesium, thorium, molybdenum, barium, strontium, beryllium, cesium, sodium, potassium, gallium, germanium, tin, wolfram, tantalum, bismuth, titanium, rhodium, thallium, silicon) (as above, except for boron, lithium and cadmium) were analysed by inductively coupled plasma mass spectrometry.

\subsection{Apparatus and chemicals}

Determinations of all elements have been performed by using an Agilent 7500A model Inductively Coupled Plasma-Mass Spectrometer. The $\mathrm{pH}$ of solutions was adjusted by adding $\mathrm{HCl}$ and $\mathrm{NaOH}$ solutions and controlled with a Schott CG $840 \mathrm{pH}$-meter. A distilled deionized Ultra High Quality water (chemical resistivity: $18 \mathrm{M} \Omega \mathrm{cm}-1$ at $25^{\circ} \mathrm{C}$ ) obtained from a Milli-Q Plus water system (Millipore, Bedford, MA, USA) was used throughout the experiments. All chemicals, obtained from Merck (Germany), were of analytical reagent grade. YSI 556 model multiparameter instrument was used to determine physico-chemical parameters such as $\mathrm{pH}$, temperature, dissolved oxygen. 


\subsection{Data analysis}

\subsubsection{Enrichment factor}

Enrichment Factor (EF) was shown for elements using:

$$
E F=\frac{\left(C_{n} / C_{A l}\right)_{\text {Sample }}}{\left(C_{n} / C_{A l}\right)_{\text {Crust }}}
$$

Where $\left(\mathrm{C}_{\mathrm{n}} / \mathrm{C}_{\mathrm{Al}}\right)$ sample is the ratio of the concentration of the element of concern $\left(\mathrm{C}_{\mathrm{n}}\right)$ to that of $\mathrm{Al}\left(\mathrm{C}_{\mathrm{Al}}\right)$ in the sediment sample and $\left(\mathrm{C}_{\mathrm{n}} / \mathrm{C}_{\mathrm{Al}}\right)$ crust is the same ratio in an unpolluted reference sample [15]. Here, $\mathrm{Al}$ was chosen as a reference element [16].

EF can provide information about anthropogenic source from a natural origin. EF close to 1 point to a crustal origin while those greater than 10 are considered to have a non-crustal source. EF can also assist determination of the degree of metal contamination [17]. Table 2 gives 5 contamination categories based on EF values.

Table 2. Contamination categories based on EF values [17]

\begin{tabular}{ll}
\hline Factor & Mean \\
\hline $\mathrm{EF}<2$ & Deficiency to minimal enrichment \\
$\mathrm{EF}=2-5$ & Moderate enrichment \\
$\mathrm{EF}=5-20$ & Significant enrichment \\
$\mathrm{EF}=20-40$ & Very high enrichment \\
$\mathrm{EF}>40$ & Extremely high enrichment \\
\hline
\end{tabular}

\subsubsection{Geoaccumulation index}

In order to quantify metal accumulations and their contamination degree in the sediments, the geoaccumulation index (Igeo) was calculated. This index is described by the equation, where $\mathrm{Cn}$ is the total concentration of metal $n$ in the silt/clay fraction, $B_{n}$ is the geochemical background value of element $\mathrm{n}$, and 1.5 is a correction factor due to lithogenic effects. The $\mathrm{I}_{\text {geo }}$ is classified [18] with seven grades (0 to 6), ranging from no pollution to very high pollution $[17,19]$.

$$
I_{g e o}=\ln \frac{C_{n}}{1.5 B_{n}}
$$

\section{Results and discussion}

River water and sediment samples were collected during a 12-month time period (10 months for sediment samples) throughout the Lower Sakarya River. Sediments, based on their heavy metal content, have shown a toxic effect depend on the collection points. For example, iron concentrations in sediment appeared to be an important factor for controlling toxicity. When iron levels were increased or exceeded relative to the combined total of other metals, toxicity was reduced. Thus, the iron chemistry of sediments is known to control heavy metal bioavailability. In order to quantify metal accumulations and their contamination degree in the 

Table 3.

sediments, the geoaccumulation index $\left(\mathrm{I}_{g e o}\right)$ was calculated and compared with the data given in

Table 3. Seven classes of the geoaccumulation index [18]

\begin{tabular}{ccl}
\hline Class & Value & Sediment quality \\
\hline 0 & Igeo $\leq 0$ & Practically uncontaminated \\
1 & $0>$ Igeo $<1$ & Uncontaminated to moderately contaminated \\
2 & $1>$ Igeo $<2$ & Moderately contaminated \\
3 & $2>$ Igeo $<3$ & Moderately to heavily contaminated \\
4 & $3>$ Igeo $<4$ & Heavily contaminated \\
5 & $4>$ Igeo $<5$ & Heavily to extremely contaminated \\
6 & Igeo $>5$ & Extremely contaminated \\
\hline
\end{tabular}

In Table 4, Boron (530.77 ng/mL), Iron (Total) (130.56 ng/mL), Calcium (65840 ng/mL), Magnesium (29231 ng/mL), Potassium (8974 ng/mL), Silicon (6484 ng/mL), Sodium (61991 ng/mL), and Strontium $(737.25 \mathrm{ng} / \mathrm{mL})$ were recorded as the highest elemental concentrations in the Lower Sakarya River water. The highest concentrations seen in the river water belonged to the alkaline and earth alkaline elements, except for Boron which is a useful element responsible for vegetables growing to maturity.

Table 4 shows the elemental analysis results of the Lower Sakarya River sediment samples as $\mathrm{mg} / \mathrm{kg}$. When Table 4 was compared with Ontario Sediment Quality Guidelines [18] Arsenic, Mercury, Silver, Cadmium, and Cobalt showed the value below the lowest effected level. Copper indicated limits above the severe effect level, except for April and October. Zinc showed a level above the severe effect level only in January. However, the data obtained in March and October showed the data under the lowest effect level. Iron indicated data under the lowest effect level only in June and October. However, in all other months, iron showed levels under the lowest effect level. The Lead element was found below the lowest effect level in April, May and October. For other months, it showed levels above the lowest effect level. Manganese was obtained above the lowest effect level in May. Other months were shown below the lowest effect level. Finally, Nickel showed a level below the severe effect level in February and March. Other months showed the level above the severe effect level.

According to the Igeo levels given in Table 4 Antimony (3.05), Bismut (3.56), Tin (2.51), Rhodium (8.11), and Selenium (2.81) showed the Igeo levels above 2. Based on the data shown in Table 4 the river was moderately to heavily contaminated with Tin and Selenium, heavily contaminated with Antimony and Bismut, and extremely contaminated with Rhodium.

The Lower Sakarya River sediments were moderately contaminated with Copper (1.35), Lead (1.13), and Thallium (1.13). Arsenic (0.71), Zinc (0.91), Molybdenum (0.71), Tantalum (0.72), and Thorium (0.40) elements were classified as uncontaminated to moderately contaminated.

Table 4 (on dry basis) also gives the enrichment factors of the river sediments. According to the enrichment factors in the table Antimony (113.62), Bismut (189.85), Tin (66.09), Rhodium (17978.12), and Selenium (89.89) showed the EF levels above 40 [17], which indicates extremely high enrichment and a non-crustal source of contamination. High enrichment of a sediment means that the sediment is highly contaminated. Arsenic, Copper, Beryllium, Zinc, Molybdenum, Thallium, and Thorium also showed EF levels as significant enrichment. Apart from natural contributions, heavy metals may be incorporated into the aquatic system from anthropogenic sources, such as the solid and liquid wastes of industries [20]. 
Table 4. Comparison of metal contents in surface water and sediment from Lower Sakarya River (mean, minimum, maximum concentrations, $\mathrm{I}_{g e o}$ and $\mathrm{EF}$ Levels, $\mathrm{n}=6$ )

\begin{tabular}{|c|c|c|c|c|c|c|c|c|c|c|}
\hline \multirow{2}{*}{ Element } & \multicolumn{3}{|c|}{ Surface Water ng/mL } & \multirow[b]{2}{*}{ Element } & \multicolumn{3}{|c|}{ Sediment $\mu \mathrm{g} / \mathrm{g}$} & \multirow{2}{*}{$\begin{array}{l}\text { Crust } \\
(\mu \mathrm{g} / \mathrm{g})\end{array}$} & \multirow{2}{*}{$\mathbf{I}_{\mathrm{geo}}$} & \multirow{2}{*}{$\mathbf{E F}$} \\
\hline & Min & Max & Mean & & Min & Max & Mean & & & \\
\hline Aluminum & 5.00 & 75.11 & 18.31 & Aluminum & 7367.50 & 35175.00 & 22805.50 & 82000 & 0 & 1.00 \\
\hline Antimony & 3.51 & 5.00 & 4.88 & Antimony & 6.25 & 6.64 & 6.32 & 0.2 & 3.05 & 113.62 \\
\hline Arsenic & 3.73 & 13.51 & 8.88 & Arsenic & 1.68 & 7.49 & 4.74 & 2.1 & 0.41 & 8.12 \\
\hline Barium & 40.83 & 89.83 & 68.24 & Barium & 110.16 & 237.84 & 172.16 & 340 & 0 & 1.82 \\
\hline Bismuth & 1.00 & 1.11 & 1.02 & Bismuth & 1.25 & 1.65 & 1.32 & 0.025 & 3.56 & 189.85 \\
\hline Boron & 145.90 & 2327.00 & 530.77 & Germanium & 0.63 & 1.36 & 0.84 & 1.4 & 0 & 2.16 \\
\hline Cadmium & 0.10 & 5.69 & 0.61 & Tin & 8.79 & 83.89 & 40.44 & 2.2 & 2.51 & 66.09 \\
\hline Calcium & 30150 & 79300 & 65840 & Calcium & 13104.50 & 60327.50 & 34272.45 & 50000 & 0 & 2.46 \\
\hline Gallium & 0.50 & 2.42 & 1.50 & Gallium & 0.63 & 9.22 & 5.50 & 19 & 0 & 1.04 \\
\hline Iron(Total) & 54.13 & 224.50 & 130.56 & Iron (total) & 5716.25 & 26187.50 & 15486.13 & 63000 & 0 & 0.88 \\
\hline Lead & 0.10 & 1.44 & 0.43 & Lead & 15.12 & 144.15 & 46.52 & 10 & 1.13 & 16.73 \\
\hline Lithium & 11.99 & 160.91 & 88.89 & Cesium & 0.13 & 2.26 & 1.50 & 1.9 & 0 & 2.84 \\
\hline Magnesium & 10403 & 39080 & 29231 & Magnesium & 2068.75 & 7961.25 & 5498.13 & 29000 & 0 & 0.68 \\
\hline Manganese & 6.44 & 54.85 & 24.13 & Manganese & 195.50 & 475.00 & 344.37 & 1100 & 0 & 1.13 \\
\hline Molybdenum & 1.36 & 37.59 & 6.14 & Molybdenum & 1.25 & 10.54 & 3.36 & 1.1 & 0.71 & 10.98 \\
\hline Nickel & 2.42 & 6.80 & 4.35 & Nickel & 53.55 & 166.23 & 104.05 & 90 & 0 & 4.16 \\
\hline Tantalum & 0.01 & 12.80 & 3.68 & Tantalum & 0.01 & 16.58 & 5.23 & 1.7 & 0.72 & 11.06 \\
\hline Thallium & 0.10 & 12.40 & 7.00 & Thallium & 0.13 & 7.93 & 2.45 & 0.530 & 1.13 & 16.62 \\
\hline Thorium & 0.50 & 14.86 & 7.56 & Thorium & 0.63 & 23.15 & 13.47 & 6 & 0.40 & 8.07 \\
\hline Titanium & 1.00 & 5.63 & 1.79 & Titanium & 1.55 & 4048.75 & 1110.54 & 6600 & 0 & 0.61 \\
\hline Vanadium & 1.26 & 6.10 & 3.34 & Vanadium & 21.78 & 70.48 & 43.57 & 190 & 0 & 0.82 \\
\hline Wolfram & 1.00 & 6.97 & 1.66 & Wolfram & 1.19 & 4.98 & 2.56 & 190 & 0 & 0.05 \\
\hline Zinc & 5.00 & 20.16 & 7.41 & Zinc & 46.24 & 1064.00 & 295.43 & 79 & 0.91 & 13.45 \\
\hline
\end{tabular}

Concentrations of Antimony in water reached the standards established by the international and national authorities (Table 5). Chromium concentration was recorded under the limit seen in Table 5. Maximum Boron concentration surpasses national and international standards. The only standard found in the literature for Thallium was established by the US-EPA Standard. The mean Thallium concentration exceeded by more than three times the US EPA standard level. The Beryllium element also exceeded almost double the concentration limit set by US-EPA. 
Table 5. Comparison of lower Sakarya River water with national and international Standards (mg/L)

\begin{tabular}{|c|c|c|c|c|c|c|}
\hline Elements & $\begin{array}{l}\text { This } \\
\text { Study }\end{array}$ & $\begin{array}{c}\text { Drinking } \\
\text { and Usage } \\
\text { Water } \\
\text { Regs } \\
\text { Standard } \\
\text { Levels (22) }\end{array}$ & $\begin{array}{l}\text { Institute of } \\
\text { Turkish } \\
\text { Standards } \\
\text { (TS 266) } \\
(2005)(23)\end{array}$ & $\begin{array}{c}\text { European } \\
\text { Union } \\
(\text { EC) } \\
(\mathbf{1 9 9 8})(24)\end{array}$ & $\begin{array}{c}\text { World } \\
\text { Health } \\
\text { Organization } \\
(\text { WHO) } \\
(2003)(25)\end{array}$ & $\begin{array}{c}\text { US } \\
\text { Environmental } \\
\text { Protection } \\
\text { Agency } \\
\text { (USEPA) } \\
(\text { 2003) }(21)\end{array}$ \\
\hline Aluminum & 0.0183 & 0.2 & 0.2 & 0.2 & 0.2 & 0.2 \\
\hline Antimony & $<0.0049$ & 0.005 & 0.005 & 0.005 & 0.02 & 0.006 \\
\hline Arsenic & 0.0089 & 0.01 & 0.01 & 0.01 & 0.01 & 0.01 \\
\hline Barium & 0.0682 & & & & 0.70 & 2 \\
\hline Beryllium & 0.0072 & & & & & 0.0040 \\
\hline Bismuth & $<0.0010$ & & & & & \\
\hline Boron & 0.5308 & 1 & 1 & 1 & 0.5 & 0.6 \\
\hline Cadmium & 0.0006 & 0.005 & 0.005 & 0.005 & 0.003 & 0.005 \\
\hline Calcium & 65.84 & & & & & \\
\hline Chromium (total) & 0.0011 & 0.05 & 0.05 & 0.05 & 0.05 & 0.1 \\
\hline Cobalt & 0.0010 & & & & & \\
\hline Copper & 0.0018 & 2 & 2 & 2 & 2 & 1.3 \\
\hline Gallium & 0.0015 & & & & & \\
\hline Iron (total) & 0.13 & 0.2 & 0.2 & 0.2 & 0.3 & 0.3 \\
\hline Lead & 0.0004 & 0.025 & 0.01 & 0.01 & 0.01 & 0.015 \\
\hline Lithium & 0.089 & & & & & \\
\hline Magnesium & 29.23 & & & & & \\
\hline Manganese & 0.0241 & 0.05 & 0.05 & 0.05 & 0.4 & 0.05 \\
\hline Molybdenum & 0.0061 & & & & 0.07 & \\
\hline Nickel & 0.0044 & 0.02 & 0.02 & 0.02 & 0.02 & \\
\hline Potassium & 5.135 & & & & & \\
\hline Rodium & 0.0085 & & & & & \\
\hline Selenium & 0.0017 & 0.01 & 0.01 & 0.01 & 0.01 & 0.05 \\
\hline Silicon & 6.4849 & & & & & \\
\hline Sodium & 61.99 & 200 & 200 & 200 & 200 & \\
\hline Strontium & 0.7373 & & & & & \\
\hline Tantalum & 0.0037 & & & & & \\
\hline Thallium & 0.0070 & & & & & 0.0020 \\
\hline Thorium & 0.0076 & & & & & \\
\hline Titanium & 0.0018 & & & & & \\
\hline Wolfram & 0.0017 & & & & & \\
\hline Vanadium & 0.0033 & & & & & \\
\hline Zinc & 0.0074 & & & & & 5 \\
\hline
\end{tabular}

The mean physical and chemical parameters, such as Sulfate, Nitrate, Total Phosphorus, Chloride concentrations of the Lower Sakarya River Water samples in 12 sampling sites, are shown in Table 6, which indicates quality classifications of river water. The mean level of Sulfate ion was $272.82 \mathrm{mg} \mathrm{L}^{-1}$, Chloride ion was $65.51 \mathrm{mg} \mathrm{L}^{-1}$, Nitrate nitrogen was $5.18 \mathrm{mg} \mathrm{L}^{-1}$, and Total Phosphorus was $0.25 \mathrm{mg} \mathrm{L}^{-1}$. The water quality of the River is reported as $2^{\text {nd }}$ class water. 
Table 6. Quality classifications of Lower Sakarya River water

\begin{tabular}{lccccc}
\hline \multirow{2}{*}{ Water Quality Parameters } & This & \multicolumn{4}{c}{ Water Quality Classifications } \\
\cline { 3 - 6 } & Study & I & II & III & IV \\
\hline & 15.64 & $\mathbf{2 5}$ & 25 & 30 & $>30$ \\
Temperature $\left({ }^{\circ} \mathrm{C}\right)$ & $7.83-8.43$ & $\mathbf{6 . 5 - 8 . 5}$ & $6.5-8.5$ & $6.0-9.0$ & Outside $6.0-9.0$ \\
pH & 8.97 & $\mathbf{8}$ & 6 & 3 & $<3$ \\
Dissolved Oxygen $\left(\mathrm{mg} \mathrm{O}_{2} / \mathrm{L}\right)$ & 88.53 & 90 & $\mathbf{7 0}$ & 40 & $<40$ \\
Oxygen Saturation $(\%)$ & 65.51 & 25 & $\mathbf{2 0 0}$ & 400 & $>400$ \\
Chloride Ion $\left(\mathrm{mg} \mathrm{Cl}^{-} / \mathrm{L}\right)$ & 272.82 & 200 & 200 & $\mathbf{4 0 0}$ & $>400$ \\
Sulfate Ion $\left(\mathrm{mg} \mathrm{SO}_{4}=/ \mathrm{L}\right)$ & 5.18 & 5 & $\mathbf{1 0}$ & 20 & $>20$ \\
Nitrate Nitrogen $\left(\mathrm{mg} \mathrm{NO}^{-}-\mathrm{N} / \mathrm{L}\right)$ & 0.25 & 0.02 & 0.16 & $\mathbf{0 . 6 5}$ & $>0.65$ \\
Total Phosphorus $(\mathrm{mg} \mathrm{P} / \mathrm{L})^{\text {Total Dissolved Solid }(\mathrm{mg} / \mathrm{L})}$ & 644.25 & 500 & $\mathbf{1 5 0 0}$ & 5000 & $>5000$ \\
Biochemical Oxygen Demand & 4.92 & 4 & $\mathbf{8}$ & 20 & $>20$ \\
$\left(\right.$ BOD $\left._{5}\right)(\mathrm{mg} / \mathrm{L})$ & & & & & \\
\hline
\end{tabular}

Based on Table 7, the mean concentration of most elements is well below the limits for either continuous or short term use of river water for irrigation purposes. The important thing is the concentration of the Boron element which approaches the limit for continuous irrigation.

Table 7. The use of Lower Sakarya River water for Irrigation Purposes $(\mu \mathrm{g} / \mathrm{L})$

\begin{tabular}{lccc}
\hline \multirow{2}{*}{$\begin{array}{l}\text { Water Quality } \\
\text { Parameters }\end{array}$} & $\begin{array}{c}\text { This Study } \\
\text { (Mean Values) }\end{array}$ & Usage (maximum allowable levels) \\
\cline { 3 - 4 } Aluminum & 18.00 & 1000 & Short term \\
Arsenic & 8.90 & 1000 & 10000 \\
Boron & 530.77 & 750 & 2000 \\
Cadmium & 0.61 & 5 & 50 \\
Chromium (total) & 1.07 & 5000 & 20000 \\
Cobalt & 0.96 & 200 & 10000 \\
Copper & 1.83 & 200 & 5000 \\
Lead & 0.43 & 5000 & 20000 \\
Nickel & 4.35 & 500 & 2000 \\
Manganese & 24.13 & 2000 & 20000 \\
Selenium & 1.67 & 50 & 50 \\
Vanadium & 3.30 & 10000 & 10000 \\
Zinc & 7.41 & 5000 & 5000 \\
\hline
\end{tabular}

Water Pollution Control Regulations:31 Dec. 2004 (Official paper). 
Table 8. Comparison of lower Sakarya River water with national surface waters

\begin{tabular}{|c|c|c|c|c|c|c|c|c|c|c|c|c|c|c|c|}
\hline & Temp & pH & Conductivity & DO & TDS & BOD5 & $\mathrm{NO}_{3}-\mathrm{N}$ & $\mathbf{P O}_{4-\mathrm{P}}$ & Chloride & $\mathrm{SO}_{4}{ }^{2-}$ & $\mathrm{Fe}$ & Mn & $\mathbf{N a}$ & Mg & $\mathbf{B}$ \\
\hline & ${ }^{\circ} \mathrm{C}$ & & $\mu \mathrm{S} / \mathrm{cm}$ & |<--- & ------ & ----Mea & Values---- & --------- & --- $\mathrm{mg} \mathrm{L}^{-1}-$ & 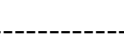 & - & - & ----. & 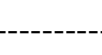 & $--->>\mid$ \\
\hline This Study & 15.64 & 8.02 & 816.77 & 8.97 & 644.25 & 4.92 & 5.18 & 0.76 & 65.51 & 272.82 & 0.13 & 0.024 & 61.99 & 29.23 & 0.53 \\
\hline Middle Sakarya River [26] & 15.50 & 8.00 & 1014.00 & 10.60 & 681.00 & 2.90 & 2.28 & 1.82 & 61.60 & 208.40 & 0.32 & 0.090 & 71.00 & 40.40 & 0.40 \\
\hline Upper Sakarya River [10] & 15.80 & 6.80 & 1123.70 & 9.10 & - & - & - & - & - & - & - & 8,36 & - & - & - \\
\hline Aksu River [27] & 15.09 & 8.24 & 353.30 & 8.60 & - & 4.17 & 2.79 & 3.16 & 16.86 & 61.25 & - & - & - & - & - \\
\hline Büyük Menderes River [1] & 19.00 & 8.20 & 1645.00 & 11.65 & - & 6.20 & - & - & - & - & - & 0.094 & - & - & - \\
\hline Gediz River [1] & 19.50 & 8.10 & 1590.00 & 11.75 & - & 6.10 & - & - & - & - & - & 0.052 & - & - & - \\
\hline Yeşilırmak River [20] & - & 7.89 & 515.00 & - & - & - & - & - & 23.75 & - & - & - & 23.22 & - & 0.96 \\
\hline
\end{tabular}


Comparison of Lower Sakarya River Water with National Surface Waters is shown in Table 8. Based on $\mathrm{pH}$ data given in Table 8 the Upper Sakarya River is the most acidic river. The lowest conductivity was observed in the Aksu river; this indicates the un-polluted river amongst other rivers in Table 8. The conductivity levels of the Sakarya river are seen to decrease from the Upper Sakarya river to the Lower Sakarya river. These results indicate that the pollution of the Sakarya river is decreasing. Total Dissolved Solid levels are seen to decrease because of the Sariyer Dam. Hovewer, Nitrate nitrogen levels were seen to increase by comparison to the Middle Sakarya river. It is beneficial to lower the phosphate levels in the river. The Sulphate level is the highest in comparison to other rivers. The Boron level is increased from the Middle Sakarya to the Lower Sakarya and exceeded the standard value established by WHO in Table 5 [25].

Table 9 indicated that Lower Sakarya River Water can be used for irrigation purposes and is classified mainly as $\mathrm{C}_{2} \mathrm{~S}_{1}$ quality, $1^{\text {st }}$ and $2^{\text {nd }}$ Class water. Briefly, river water can be used for plants sensitive to Boron levels between 0.4-0.6 mg/L, such as Peach, Apple, Pear, and Onion (Table 9). Long term irrigation of farm lands could make soils rich in Boron and result in poor or unsuitable soils.

Table 9. Agricultural Irrigation Quality Parameters of Lower Sakarya River Water.

\begin{tabular}{|c|c|c|c|c|c|c|}
\hline & \multirow[b]{2}{*}{ This Study } & \multicolumn{5}{|c|}{ Water Quality Classifications } \\
\hline & & $\begin{array}{c}\text { I. Class } \\
\text { (Excellent) }\end{array}$ & $\begin{array}{c}\text { II. Class } \\
\text { (Good) }\end{array}$ & $\begin{array}{l}\text { III. Class } \\
\text { (Fair) }\end{array}$ & $\begin{array}{l}\text { IV. Class } \\
\text { (Poor) }\end{array}$ & $\begin{array}{c}\text { V. Class } \\
\text { (Unsuitable) }\end{array}$ \\
\hline $\mathrm{EC}_{25} \times 10^{6}$ & 816.77 & $0-250$ & $250-750$ & $750-2000$ & $2000-3000$ & $>3000$ \\
\hline $\begin{array}{l}\text { Sodium Adsorption } \\
\text { Rate } \\
\text { (SAR) }\end{array}$ & 0.61 & $<10$ & $10-18$ & $18-26$ & $>26$ & \\
\hline Chloride (mg/L) & 65.51 & $0-142$ & $142-249$ & $249-426$ & $426-710$ & $>710$ \\
\hline Total Salinity & 490 & $0-175$ & $175-525$ & $525-1400$ & $1400-2100$ & $>2100$ \\
\hline Boron $(\mathrm{mg} / \mathrm{L})$ & 0.54 & $0-0.5$ & $0.5-1.12$ & $1.12-2.0$ & $>2.0$ & \\
\hline Irrigation Classification & $\mathrm{C}_{2} \mathrm{~S}_{1}$ & $\mathrm{C}_{1} \mathrm{~S}_{1}$ & $\begin{array}{c}\mathrm{C}_{1} \mathrm{~S}_{2}, \mathrm{C}_{2} \mathrm{~S}_{2} \\
\mathbf{C}_{2} \mathbf{S}_{\mathbf{1}}\end{array}$ & $\begin{array}{c}\mathrm{C}_{1} \mathrm{~S}_{3}, \mathrm{C}_{2} \mathrm{~S}_{3}, \\
\mathrm{C}_{3} \mathrm{~S}_{3}, \mathrm{C}_{3} \mathrm{~S}_{2}, \\
\mathrm{C}_{3} \mathrm{~S}_{1}\end{array}$ & $\begin{array}{c}\mathrm{C}_{1} \mathrm{~S}_{4}, \mathrm{C}_{2} \mathrm{~S}_{4} \\
\mathrm{C}_{3} \mathrm{~S}_{4}, \mathrm{C}_{4} \mathrm{~S}_{4} \\
\mathrm{C}_{4} \mathrm{~S}_{3}, \mathrm{C}_{4} \mathrm{~S}_{2}, \mathrm{C}_{4} \mathrm{~S}_{1}\end{array}$ & \\
\hline $\mathrm{NO}_{3}{ }^{-}(\mathrm{mg} / \mathrm{L})$ & 5.18 & $0-5$ & $5-10$ & $10-30$ & $30-50$ & $>50$ \\
\hline $\mathrm{BOD}_{5}(\mathrm{mg} / \mathrm{L})$ & 4.92 & $0-25$ & $25-50$ & $50-100$ & $100-200$ & $>200$ \\
\hline $\mathrm{pH}$ & 8.02 & $6.5-8.5$ & $6.5-8.5$ & $6.5-8.5$ & $6.0-9.0$ & $<6$ or $>9$ \\
\hline Water Temp. $\left({ }^{\circ} \mathrm{C}\right)$ & 15.64 & $<30$ & 30 & 35 & 40 & $>40$ \\
\hline
\end{tabular}

\section{Conclusions}

In conclusion, the Sakarya River water was affected by the construction of a highway, the connection of small creeks which carry pollution to the river, and by industrial and municipality pollution. The effects of these pollution sources can be minimised by recycling, stopping construction, decreasing sewage discharge. Lower Sakarya River water can be used for continuous irrigation purposes, but not for a long term use. Ontario Sediment Quality Guidelines was used for River sediments. Physical and inorganic-chemical parameters indicate that river water is represented as $2^{\text {nd }}$ class water. Water pollution parameters, such as Thallium and Beryllium, exceeded the US EPA standards.

\section{Acknowledgements}

This study (Project No: 106Y037) was supported by CAYDAG group of the Scientific and Technological Research Council of Turkey.

\section{ORCID}

Mustafa Sahin Dundar : 0000-0002-5117-7864

Huseyin Altundag: 0000-0002-3675-4133 


\section{References}

[1] H. Akçay, A. Oguz, and C. Karapire (2003), Study of heavy metal pollution and speciation in Buyuk Menderes and Gediz river sediments, Water Res. 37(4), 813-822.

[2] F. Yilmaz (2006). Bioaccumulation of heavy metals in water, sediment, aquatic plants and tissues of Cyprinus carpio from Kizilirmak, Turkey, Fresen. Environ. Bull. 15, 360-369.

[3] M. Tuzen, E. Aydemir and H. Sari (2002). Investigation of some physical and chemical parameters in the river Yesilirmak in Tokat region, Turkey, Fresen. Environ. Bull., 11, 202-207.

[4] H. Karadede and E. Unlu (2000). Concentrations of some heavy metals in water, sediment and fish species from the Atatürk Dam Lake (Euphrates), Turkey, Chemosphere 41(9), 1371-1376.

[5] B. Gumgum, E. Unlu and Z. Tez (1994), Heavy metal pollution in water, sediment and fish from the Tigris River in Turkey, Chemosphere. 29 (1), 111-116.

[6] G. Bakan, and B. Senel (2000), Samsun Mert Irmağı-Karadeniz deşarjında yüzey sediman (dip camur) ve su kalitesi araştırması, Turk. J. Engin. Environ. Sci. 24, 135 -141.

[7] M.W. Aktar, M. Paramasivam, M. Ganguly, S. Purkait and D. Sengupta, (2010). Assessment and occurrence of various heavy metals in surface water of Gang river around Kolkata: A study for toxicity and ecological impact, Environment. Monit. Assess. 160(1-4), 207-213.

[8] O. Minareci, M. Cakir and E. Minareci. (2018). The study of water quality in Buyuk Menderes River (Turkey): Determination of anionic detergent, phosphate, boron and some heavy metal contents, Appl. Ecol. Env. Res. 16 (4), 5287-5298.

[9] A. Elzwayie, H. A. Afan, M. F. Allawi, A. El-Shafie (2017). Heavy metal monitoring, analysis and prediction in lakes and rivers: state of the art, Environ. Sci. Pollut. R. 24(13), 12104-12117.

[10] N. Barlas (1999), A pilot study of heavy metal concentration in various environments and fishes in the upper Sakarya River basin, Turkey, Environment. Toxicol. 14(3), 367-373.

[11] Mustafa S. Dundar, H. Altundag, V. Eyupoglu, C.S. Keskin, and C. Tutunoglu (2012). Determination of heavy metals in lower Sakarya river sediments using a BCR-sequential extraction procedure, Environment. Monitor. Assessm. 184(1), 33-41.

[12] P.F. Landrum, and Robbins, J.A. (1990). Bioavailability of sediment-associated contaminants to benthic invertabres in Sediments: Chemistry and toxicity of in-place pollutants edited by: R. Baudo, J.P. Giesy, H. Muntau, Chem. Tox. in-place Pollut. 237-263.

[13] O.L. Vigano, A. Arillo, C. Falugi and F. Melodia (1998). Historical and biochemical markers in trout larvae exposed to river sediments, Chemosphere 37, 2797-2807.

[14] Coğrafi Bilgi Sistemleri Merkezi (CBSM), Sakarya Valiliği, Adapazarı Sakarya / Turkey.

[15] H. Pekey (2006), Heavy metal pollution assessment in sediments of the Izmit Bay, Turkey, Environment. Monitor. Assessm. 123(1-3), 219-231.

[16] V.K. Mishra, K.H. Kim, C.H. Kang and K.C. Choi (2004), Wintertime sources and distribution of airborne lead in Korea, Atmos. Environm. 38 (17), 2653-264.

[17] M. Chakravarty and A.D. Patgiri (2009). Metal pollution assessment in sediments of the Dikrong River, NE India, 27(1), 63-67.

[18] Ontario Ministry of Environment and Energy, guidelines for the protection and management of aquatic sediment quality in Ontario. (http://www.ene.gov.on.ca/envision/gp/B1-3.pdf) (1993).

[19] Maria Lucia Kolowski Rodrigues and Milton Luiz Laquintinie Formoso (2006). Heavy metals in recent sediments and bottom-fish under the influence of tanneries in South Brazil, Water Air Soil Poll. 169, 167-184.

[20] M. Tüzen (2003). Determination of trace metals in the river Yeşilırmak sediments in Tokat, Turkey using sequential extraction procedure, Microchem. J. (74), 105-110.

[21] United State Environmental Protection Agency (US EPA), (2003). Washington, USA.

[22] Drinking and usage water regulations standard levels, (2005). Official Newspaper, 25730.

[23] TS 266 (2005). Water intended for human consumption, TSE, Ankara, Turkey.

[24] Council Directive 98/83/EC, (1998). The quality of water intended for human consumption. 
[25] WHO (2003). Boron in drinking water. Background document for preparation of WHO Guidelines for drinking-water quality. Geneva, World Health Organization (WHO/SDE/WSH/03.04/54).

[26] Bilecik municipality environmental status report (2006). Bilecik governship directory of city environent and forest, p. 108.

[27] H. Kalyoncu, M. Barlas, Ö. O. Ertan and K. Çavuşoğlu (2005). Aksu Çayı'nın su kalitesi değişimi üzerine bir araştırma, Süleyman Demirel Üniv. Fen Bil. Enst. Derg. (9), 5-13.

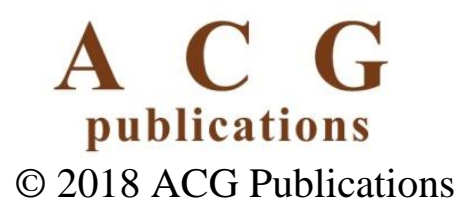

